\title{
Rezime
}

Za većinu ljudi je stohastički kalkulus zastrašujući te zaobilaze njegove kompleksne jednačine. Iako ne postoji način da se one pojednostave, cilj ovog rada je da neke od široko korišćenih koncepata za utvrđivanje cena finansijskih derivata dovedemo u vezu sa praktičnim opservacijama tržišta. Nedavna finansijska kriza je donela mnoge negativne ekonomske promene, ali je i poljuljala neka dugogodišnja uverenja, kao što je, recimo, to da će kamatne stope uvek ostati pozitivne. Iako se debata o njenim tačnim uzrocima verovatno nikada neće privesti kraju, mnogi krive kompleksne derivate i modele u njihovoj osnovi. Sa druge strane, kvantitativni analitičari koji su te modele razvili tvrde da je matematički proračun bio tačan, ali da su dotični kompleksni proizvodi pogrešno prodavani. Bez obzira na to na čijoj ste strani, niko ne može da tvrdi da se stohastičke diferencijalne jednačine i integrali $u$ osnovi većine modela za utvrđivanje cena derivata ne mogu lako dovesti u vezu sa konkretnim kretanjima na tržištu. U ovom radu se Markovljev i Vinerov proces - osnove finansijskog kalkulusa - objašnjavaju u odnosu na prinos na investicije, putem tržišne cene rizika.

Ključne reči: stohastičke varijable, Markovljev proces, Vinerov proces, Itoov proces, tržišna cena rizika

JEL: D81, G17 


\section{MARKET PRICE OF RISK}

\section{Nataša Kožul}

Independent expert and investment banking consultant nkozul@gmail.com
The original version of the text is in English

\section{Summary}

Most people find stochastic calculus intimidating and skip through complex equations. While there is no way of simplifying them, this work is an attempt to relate some of the widely used concepts in pricing financial derivatives to the practical market observations. Recent financial crisis has brought many adverse economic changes, but has also challenged the long-standing beliefs, such as that interest rates will always remain positive. Although the debate on its exact causes is unlikely to be settled, many blame complex derivatives and underlying models. Quantitative analysts that developed them, on the other hand, claim that the math was correct, but the complex products were mis-sold. Regardless of what side one wishes to take, the fact remains that the stochastic differential equations and integrals underlying most derivatives pricing models cannot be easily related to the actual market movements. Here, Markov and Wiener processes - the cornerstones of financial calculus - are explained in relation to return on investment, via market price of risk.

Keywords: stochastic variables, Markov process, Wiener process, Ito process, market price of risk

JEL: D81, G17 


\section{Uvod}

Svako ko počne da izučava finansijsku matematiku prvo će biti upoznat sa razlikom između determinističkih i stohastičkih procesa, budući da se jednačine primenljive na prvi od ovih procesa ne mogu lako primenjivati na drugi bez nekih važnih pretpostavki. Jednostavno rečeno, za varijablu čija se vrednost menja tokom vremena na način koji ne prati neki predvidljiv (deterministički) šablon, smatra se da prati stohastički proces. $\mathrm{U}$ okviru tog procesa dalje potrebno je razlikovati diskretno vreme i kontinuirano vreme, $\mathrm{u}$ zavisnosti od toga da li se promene dešavaju u specifičnim, fiksno definisanim momentima ili se odigravaju kontinuirano. Slično tome, stohastički procesi mogu obuhvatati diskretne varijable ili kontinuirane varijable, pri čemu posmatrane varijable mogu menjati vrednost samo u izvesnim diskretnim iznosima ili mogu uzeti bilo koju vrednost $\mathrm{u}$ okviru specifičnog intervala.

Dok se stohastički kalkulus fokusira na stohastičke procese kontinuiranih varijabli i kontinuiranog vremena, cene akcija, primera radi, mogu menjati vrednost samo u unapred određenom iznosu. Uprkos tome, ovaj pristup se primenjuje $\mathrm{u}$ finansijskom modeliranju jer omogućava korišćenje nekih ključnih koncepata prilikom utvrđivanja cena čak $\mathrm{i}$ za najkompleksnije finansijske derivate. To su Markovljev, Vinerov i Itoov proces, koje ukratko predstavljamo u nastavku. Više detalja o ovim procesima i finansijskom modeliranju možete naći u nekim odličnim izvorima, kao što su Harrison (1985), Hull (1997), Jarrow i Turnbull (1996), Kushner (1995), Musiela i Rutkowski (1997), Neftci (2000), Wilmot, Howison i Dewyanne (1995), i Wilmott (2007).

\section{Markovljev proces}

Markovljev proces je poseban tip stohastičkog procesa $\mathrm{u}$ kome naredna vrednost varijable zavisi samo od njene trenutne vrednosti (Hull, 1997). Stoga se pretpostavlja da je ona uslovno nezavisna od svih prethodnih vrednosti date varijable. Drugim rečima, da bi se predvidelo ponašanje procesa u budućnosti, dovoljno je znati njegovo trenutno stanje, budući da ono već sadrži sve prethodne vrednosti varijable. Ova definicija je prilično intuitivna, ako pretpostavimo da na početku svakog procesa donošenja odluke treba sagledati sve raspoložive informacije i napraviti najoptimalniji izbor $\mathrm{u}$ tom trenutku. $\mathrm{U}$ svakom konsekutivnom koraku, koriste se nove relevantne informacije kako bi se donela sledeća odluka, i tako dalje. Dakle, nije relevantno kako smo dostigli specifično stanje, pošto sve što možemo da uradimo jeste da iz njega krenemo dalje koristeći raspoložive podatke.

Markovljev proces nosi ime po Andreju Markovu, koji je svoj prvi rad na ovu temu objavio 1906. godine, iako su ovakvi procesi bili primenjivani i ranije (Grinstead \& Snell, 1997; Meyn \& Tweedie, 2009). Recimo, slučajna šetnja po brojnoj osi i problem propasti kockara, dva primera Markovljevih procesa u diskretnom vremenu, izučavani su stotinama godina pre toga. $S$ druge strane, najpoznatiji Markovljevi procesi $\mathrm{u}$ kontinuiranom vremenu jesu Vinerov proces (o kome govorimo u narednom segmentu), poznat i kao Braunovo kretanje, i Poasonov proces, pri čemu su ova dva procesa otkrivena nezavisno u različitim kontekstima.

Slučajna šetnja po brojnoj osi je najjednostavniji primer diskretnog stohastičkog procesa, budući da počinje od 0 i kreće se za +1 ili -1 u svakom koraku sa jednakom verovatnoćom (Weiss, 1994). Može se bacati novčić da bi se utvrdilo da li će promena biti na gore ili na dole, što će rezultirati rešetkom svih potencijalnih putanja koje se mogu desiti, i njihovih odgovarajućih celih vrednosti. Ovo ima primenu prilikom utvrđivanja cena jednostavnih opcija na akcije, ali se takođe $u$ velikoj meri koristi u ekologiji, hemiji, fizici, psihologiji, itd, kada su neophodne samo diskretne tačke podataka.

Slično tome, problem propasti kockara je čuveni paradoks koji kaže da konstantno uzimanje povoljnih rizika nikada neće rezultirati povoljnim ishodom. Zasniva se na logici da čak i ako kockar igra pošteno (sa šansom od 0,5 da pobedi), on će na kraju ili duplirati svoj novac ili izgubiti sve ako ne prilagodi veličinu opklade iznosu koji i dalje poseduje. Ova tvrdnja proističe iz činjenice da svaki konsekutivni ishod zavisi od prethodnog, tako da je u prvom krugu kockanja šansa za pobedu 0,5 (pre nego 


\section{Introduction}

Anyone starting to learn financial mathematics will be first introduced to the difference between deterministic and stochastic processes, as the equations applicable to the former cannot be easily applied to the latter without some important assumptions. Put simply, a variable whose value changes over time in a way that does not follow any predictable (deterministic) pattern is said to follow a stochastic process. This process can be further classified into discrete time and continuous time, depending on whether the changes occur at specific fixed points in time, or take place continuously. Similarly, stochastic processes can be discrete variable or continuous variable, whereby the observed variable can change value only by certain discrete amounts, or can take any value within a specific interval.

While in stochastic calculus the focus is on continuous-variable, continuous-time stochastic processes, stock prices, for example, can only change value by a predetermined amount. Still, this approach is taken in financial modelling, as it allows employing some key concepts when pricing even the most complex financial derivatives. Those are Markov, Wiener and Ito process, briefly discussed below. More details on these processes and financial modelling can be found in some excellent sources, including Harrison (1985), Hull (1997), Jarrow and Turnbull (1996), Kushner (1995), Musiela and Rutkowski (1997), Neftci (2000), Wilmot, Howison, and Dewyanne (1995), and Wilmott (2007).

\section{Markov Process}

Markov process is a special type of stochastic process in which the next value of the variable depends on its current value only (Hull, 1997). Thus, it is assumed to be conditionally independent of any previous values of the variable. In other words, to predict the behaviour of the process in the future, it is sufficient to know its current state, as all preceding variable values are already contained in this state. This definition is rather intuitive, if we assume that at the start of any decision-making process one considers all available information and makes the most optimal choice at that time. In each consecutive step, pertinent new information is used to make the next decision, and so on. Thus, it is not relevant how we reached a specific state, as all we can do is move forward from it using the available data.

Markov process is named after Andrey Markov, who published his first paper on the topic in 1906, even though earlier applications of such processes already existed (Grinstead $\mathcal{E}$ Snell, 1997; Meyn \& Tweedie, 2009). For example, random walks on the integer and the Gambler's ruin problem, both of which are Markov processes in discrete time, were studied hundreds of years earlier. On the other hand, the most widely known Markov processes in continuous time are the Wiener process (discussed in the next section), also known as the Brownian motion process, and the Poisson process, both of which were discovered independently in various contexts.

The random walk on the integer number line is the simplest example of a discrete stochastic process, as it starts at 0 and moves +1 or -1 at each step with equal probability (Weiss, 1994). A coin can be tossed to determine if move would be up or down, resulting in a lattice of all potential paths that can be taken, and their corresponding integer values. It finds applications in simple stock option pricing, but is also widely used in ecology, chemistry, physics, psychology, etc., when only discrete data points are required.

Similarly, Gambler's ruin problem is a famous paradox stating that persistently taking beneficial chances will never result in beneficial outcome. It is based on the logic that even if the gambler is playing a fair game (with 0.5 probability of winning), he will eventually either double his wealth or lose all the money if he does not adjust the size of the bet to the amount he still owns. This statement is derived from the fact that each consecutive outcome is conditional on the preceding one, so that there is 0.5 chance of win in the first round of betting (before either losing it all or doubling the money), 0.25 in the second (as there is now $0.5 \times 0.5$ chance of a win, given the outcome of the preceding step), 0.125 in the third, and so on. As the cumulative probability approaches 1 , such betting strategy will result in almost certain ruin (Shoesmith, 1986). 
što se ili izgubi sve ili duplira novac), $u$ drugom krugu 0,25 (pošto je sada šansa za pobedu 0,5×0,5, uzimajući u obzir ishod prethodnog koraka), u trećem krugu 0,125, i tako dalje. Kako se kumulativna verovatnoća približava jedinici, takva kockarska strategija je osuđena na skoro sigurnu propast (Shoesmith, 1986).

Dva gore pomenuta stohastička procesa kontinuiranog vremena, Braunovo kretanje i Poasonov proces, imaju brojne primene $\mathrm{u}$ praksi, od teorije redova čekanja do modela nasumičnih događaja, uključujući dolazak putnika na aerodrom ili telefonske pozive $u$ korisničkom centru, devizne kurseve, sisteme za skladištenje kao što su brane, rast populacije izvesnih životinjskih vrsta, izučavanje sistema za kontrolu upravljanja u motornim vozilima, i mnoge druge.

Braunovo kretanje je dobilo naziv po botaničaru Robertu Braunu, koji je prvi uočio nasumično kretanje čestica u fluidu (koji može biti tečnost ili gas) kao rezultat njihove kolizije sa atomima ili molekulima koji se rapidno kreću u dotičnom gasu ili tečnosti. Iako Braunov proces ima mnoge primene, njegova upotreba u finansijskom kalkulusu je motivisana činjenicom da limitira i jednostavnije i kompleksnije stohastičke procese, na sličan način kao univerzalnost normalne distribucije (Morozov \& Skripkin, 2011).

Poasonov proces je posebno koristan kada postoji potreba da se prati neki podskup podataka, budući da se zasniva na premisi da, ukoliko zbir nasumičnih tačaka formira Poasonov proces, onda izvestan broj tačaka u podskupu izvučenom iz ovog većeg skupa predstavlja nasumičnu varijablu sa Poasonovom distribucijom (Johnson, Kotz, \& Kemp, 1993). Štaviše, brojevi tačaka u disjunktnim intervalima su nezavisne nasumične varijable (poznate i kao svojstva bez memorije - eng. memoryless properties). Ove karakteristike omogućavaju primenu Poasonovog procesa $\mathrm{u}$ različitim okolnostima, uključujući eksperimente vezane za raspadanje radioaktivnih materijala $i$ matematiku osiguranja. Iznenađujuće, iako je proces nazvan po francuskom matematičaru Poasonu, on ga nikada nije izučavao. Nakon što smo predstavili neke činjenice o ovim stohastičkim konceptima, u nastavku ćemo ukratko opisati Vinerov proces, pošto je on $\mathrm{u}$ osnovi većine finansijskih proračuna.

\section{Vinerov proces}

Vinerov proces nosi ovo ime $u$ čast američkog matematičara i filozora Norberta Vinera. I dok ovaj stohastički proces kontinuiranog vremena ima mnoge primene u matematici i fizici, ovde će fokus biti na njegovoj upotrebi u finansijskom kalkulusu (Neftci, 2000).

Razmotrimo ponašanje varijable $z$, koja prati Vinerov proces, u smislu promena njene vrednosti tokom kratkih vremenskih intervala (Hull, 1997). Ukoliko označimo dužinu takvog vremenskog intervala sa $\Delta t$, promena varijable $z$ koja se može uočiti u tom intervalu biće predstavljena sa $\Delta z$. Da bi varijable $z$ pratila Vinerov proces, ona mora da poseduje dva važna svojstva.

Svojstvo 1. Vrednosti $\Delta z$ u bilo koja dva kratka vremenska intervala $\Delta t$ moraju biti nezavisne (tj., nedeterminističke). To je neophodno da bi se varijabla ponašala nasumično, odnosno pratila Markovljev proces.

Svojstvo 2. Vrednosti $\Delta z \mathrm{su}$ u sledećem odnosu prema kratkim vremenskim intervalima $\Delta t:$

$$
\Delta z=\varepsilon \sqrt{ } \Delta t \quad(1)
$$

gde je $\varepsilon$ vrednost nasumično izvučena iz standardizovane normalne distribucije (tj., distribucije u obliku zvona čija je srednja vrednost nula a standardna devijacija jedan).

Odnos između $\Delta z$ i $\Delta t$ ukazuje da se promene varijable $z$ dešavaju usled nasumičnih promena njene vrednosti i protoka vremena, ali i da su promene vrednosti takođe $\mathrm{u}$ funkciji vremena (primera radi, cena opcije će tipično beležiti manje fluktuacije kada se bliži dospeću, pošto ima manje vremena da se promene odigraju, čime se smanjuje neizvesnost). $S$ druge strane, uskoro će postati jasna tačna veza između ove dve vrednosti, tj., $\Delta z=\varepsilon \sqrt{ } \Delta t$.

Iz Svojstva 2 sledi da je $\Delta z$ takođe normalno distribuirano pri čemu je srednja vrednost $M(\Delta z)=0$, standardna devijacija $S D(\Delta z)=\sqrt{ } \Delta t$, a varijansa $\operatorname{var}(\Delta z)=\Delta t$.

$S$ obzirom na to da bismo tipično bili zainteresovani za duži period vremena tokom koga se vrednost varijable $z$ razvija, on se može označiti sa $T$ koje obuhvata $N \Delta t$ priraštaje, pri čemu se $z$ menja kao $z(T)-z(0)$. Budući da je 
The two continuous-time stochastic processes mentioned above, Brownian motion process, and the Poisson process, have numerous applications in practice, such as in queueing theory to model random events, including arrival of travellers at the airport or phone calls at a customer service centre, currency exchange rates, storage systems such as dams, population growths of certain animal species, studying cruise control systems in motor vehicles, and many others.

Brownian motion is named after the botanist Robert Brown, who first observed the random motion of particles suspended in fluid (which can be either liquid or gas) resulting from their collision with the rapidly moving atoms or molecules in the gas or liquid. While Brownian process has many applications, its use in financial calculus is motivated by the fact that is a limit of both simpler and more complex stochastic processes, akin to universality of normal distribution (Morozov E Skripkin, 2011).

Poisson process is particularly useful when there is a need to observe a certain subset of data, as it is based on the premise that, if a collection of random points forms a Poisson process, then the number of points in a subsample drawn from this larger set is a random variable with a Poisson distribution (Johnson, Kotz, \& Kemp, 1993). In addition, the numbers of points in disjoint intervals are independent random variables (also known as memoryless property). These characteristics allow Poisson process usage in different settings, including radioactive decay experiments and insurance mathematics. Surprisingly, although it is named after French mathematician Poisson, he never studied it. Having introduced some real-world facts about these stochastic concepts, Wiener process is briefly described below, as it underlies most financial calculations.

\section{Wiener Process}

Wiener process is named in recognition of the work of American mathematician and philosopher Norbert Wiener. While this continuous-time stochastic process has many applications in mathematics and physics, here, the focus will be on its use in financial calculus (Neftci, 2000).
Consider the behaviour of variable $z$, which follows a Wiener process, in terms of the changes in its value in short time intervals (Hull, 1997). If denote the length of such time interval as $\Delta t$, the change in $z$ that can be observed in that interval will be represented by $\Delta z$. For the variable $z$ to follow a Wiener process, it must possess two important properties.

Property 1 . The values of $\Delta z$ in any two short time intervals $\Delta t$ must be independent (i.e., non-deterministic). This is necessary for the variable to behave randomly, i.e., to follow a Markov process.

Property 2. The values of $\Delta z$ are related to the short time intervals $\Delta t$ by:

$$
\Delta z=\varepsilon \sqrt{ } \Delta t
$$

where $\varepsilon$ is a value drawn randomly from a standardized normal distribution (i.e., the bellshaped distribution with the mean of zero and standard deviation of one).

This relationship between $\Delta z$ and $\Delta t$ indicates that changes in $z$ occur both due to random shifts in its value and passage of time, but shifts in value are also a function of time (for example, price of option will typically fluctuate less close to maturity, as there is less time for large changes to take place, thus reducing the uncertainty). On the other hand, the precise link between these two values, i.e., $\Delta z=\varepsilon \sqrt{ } \Delta t$ will become clear shortly.

From Property 2, it follows that $\Delta z$ is also normally distributed with mean $M(\Delta z)=0$, standard deviation $S D(\Delta z)=\sqrt{ } \Delta t$, and variance $\operatorname{var}(\Delta z)=\Delta t$.

As we would typically be interested in a longer period in which the value of $z$ develops, it can be denoted by $T$ comprising of $N \Delta t$ increments, whereby $z$ changes by $z(T)-z(0)$. As this difference is a result of small changes that take place in each consecutive short interval $\Delta t$, it can be stated:

$$
z(T)-z(0)=\sum_{k=1}^{N} \square \varepsilon_{\mathrm{k}} \sqrt{ } \Delta t
$$

where $\varepsilon_{k}(k=1,2,3, \ldots, N)$ are, as noted earlier, random drawings from a standardized normal distribution $(M=0, S D=1)$ and are, due to Property 1, independent from one another. Consequently, $z(T)-z(0)$ is also normally distributed with:

$$
\begin{gathered}
M[z(T)-z(0)]=0 \\
S D[z(T)-z(0)]=\sqrt{ } T \\
\operatorname{var}[z(T)-z(0)]=N \Delta t=T
\end{gathered}
$$


ova razlika rezultat malih promena koje se odigravaju u svakom konsekutivnom kratkom intervalu $\Delta t$, može se tvrditi sledeće:

$$
z(T)-z(0)=\sum_{k=1}^{N} \square \varepsilon_{\mathrm{k}} \sqrt{ } \Delta t
$$

gde su $\varepsilon_{k}(k=1,2,3, \ldots, N)$, kao što je spomenuto ranije, nasumično izvučene vrednosti iz standardizovane normalne distribucije $(M=0, S D=1)$, koje su, zahvaljujući Svojstvu 1, međusobno nezavisne. Posledično, $z(T)-z(0)$ je takođe normalno distribuirano, pri čemu je:

$$
\begin{gathered}
M[z(T)-z(0)]=0 \\
S D[z(T)-z(0)]=\sqrt{ } T \\
\operatorname{var}[z(T)-z(0)]=N \Delta t=T
\end{gathered}
$$

Imajući $u$ vidu da su varijanse aditivne za nezavisne normalne distribucije, dok standardne devijacije nisu, originalni odabir odnosa između $\Delta z$ i $\Delta t(\Delta z=\varepsilon \sqrt{ } \Delta t)$ je postavljen tako da iskoristi to svojstvo.

Nakon što smo prikazali ove osnovne elemente, njihova primena u utvrđivanju cena derivata biće ilustrovana u nastavku.

\section{Opšti pristup utvrđivanju cena derivata}

Posmatraćemo finansijski derivat koji zavisi od vrednosti jedine varijable $S$ koja prati stohastički proces:

$$
d S / S=s d t+v d z
$$

gde su $s$ i $v$ očekivana stopa rasta i volatilnost u $S$, koji zavise samo od $S$ i $t$.

Hajde da sada sa $p_{1}$ i $p_{2}$ označimo cene dva derivata (recimo, opcije ili fjučerse) koje zavise od ove varijable $S$ i vremena $t$. Pošto $S$ i sama zavisi od vremena, ovi derivati prate generalizovani Vinerov proces, poznat kao Itoov proces, $\mathrm{u}$ kome obe varijable zavise od osnovne varijable i vremena. To se izražava na sledeći način:

$$
d x=a(x, t) d t+b(x, t) d z
$$

Kada ovaj koncept primenimo na derivate $p_{1}$ i $p_{2}$ dobijamo:

$$
d p_{1} / p_{1}=\mu_{1} d t+\sigma_{1} d z
$$

$$
d p_{2} / p_{2}=\mu_{2} d t+\sigma_{2} d z
$$

gde su $\mu_{1}, \mu_{2}, \sigma_{1} \mathrm{i} \sigma_{2}$ funkcije od $S \mathrm{i} t$, kao što je navedeno iznad, a $d z$ je isti Vinerov proces koji upravlja ponašanjem varijable $S$. Kada uzmemo diskretne verzije ovih izraza, procesi koje $p_{1}$ i $p_{2}$ prate prikazuju se kao:

$$
\Delta p_{1}=\mu_{1} p_{1} \Delta t+\sigma_{1} p_{1} \Delta z
$$

i

$$
\Delta p_{2}=\mu_{2} p_{2} \Delta t+\sigma_{2} p_{2} \Delta z
$$

Stohastički element $\Delta z$ se može eliminisati iz ove dve jednačine kreiranjem momentalno bezrizičnog portfolija koji sadrži $\sigma_{2} p_{2} \mathrm{u}-\sigma_{1} p_{1}$ iz prvog i drugog derivata, respektivno. Drugim rečima, portfolio sadrži:

$$
\mathrm{P}=\left(\sigma_{2} p_{2}\right) p_{1}-\left(\sigma_{1} p_{1}\right) p_{2}
$$

i menja vrednost:

$$
\Delta \mathrm{P}=\sigma_{2} p_{2} \Delta p_{1}-\sigma_{1} p_{1} \Delta p_{2}
$$

Zamenjivanjem $\Delta p_{1}$ i $\Delta p_{2}$ odgovarajućim izrazima datim pod (6) i (7), dobijamo:

$$
\Delta \mathrm{P}=\left(\mu_{1} \sigma_{2} p_{1} p_{2}-\mu_{2} \sigma_{1} p_{1} p_{2}\right) \Delta t
$$

Budući da je eliminacija $\Delta z$ učinila portfolio momentalno bezrizičnim, on po definiciji zaslužuje bezrizičnu kamatnu stopu $r$, tako da važi sledeće:

$$
\Delta \mathrm{P}=r \mathrm{P} \Delta t
$$

Zamenjivanjem izraza za $\mathrm{P}$ i $\Delta \mathrm{P}$ datih pod (9) i (10), respektivno, u (11) dobijamo:

$$
\mu_{1} \sigma_{2}-\mu_{2} \sigma_{1}=\sigma_{2} r-\sigma_{1} r
$$

što se može predstaviti i na drugi način (Hull, 1997):

$$
\left(\mu_{1}-r\right) / \sigma_{1}=\left(\mu_{2}-r\right) / \sigma_{2}
$$

Iz svega navedenog vidimo da su razlika između očekivanog prinosa na hartiju od vrednosti i bezrizična kamatna stopa povezane sa osnovnom volatilnošću, pri čemu investitori mogu da očekuju veće prinose za volatilnije finansijske instrumente kako bi oni ostali konkurentni na tržištu.

\section{Tržišna cena rizika}

Ako gornji racio označimo sa $\lambda$, vidimo da za svaki par $\mu$ i $\sigma$ važi sledeće:

$$
\lambda=(\mu-r) / \sigma
$$

Kako $\lambda$ i $\sigma$ zavise od originalne varijable $S$ i vremena $t$, oni su generalno nezavisni od tipa i karakteristika derivata na koji se odnose (u ovom slučaju $p_{1}$ i $p_{2}$ ). Drugim rečima, $\lambda$ predstavlja tržišnu cenu rizika vezanog za varijablu $S$.

Budući da $\mu$ i $\sigma$ označavaju očekivani prinos na derivat $p$ i njegovu volatilnost, respektivno, kako se volatilnost povećava, investitori će zahtevati veću razliku između $\mu$ i $r$ (preovlađujuća bezrizična kamatna stopa na tržištu), što je intuitivni rezultat. Ovim su dovedeni u vezu neki od veoma 
As variances are additive for independent normal distributions, while standard deviations are not, the original choice of relationship between $\Delta z$ and $\Delta t(\Delta z=\varepsilon \sqrt{ } \Delta t)$ was made to utilize this property.

Having provided these basic elements, their application in derivatives pricing will be given below.

\section{General Approach to Pricing Derivatives}

Let us consider a financial derivative dependent on the value of a single variable $S$ that follows a stochastic process:

$$
d S / S=s d t+v d z \quad(3)
$$

where $s$ and $v$ are the expected growth rate and volatility in $S$, which are dependent only on $S$ and $t$.

Now, let us denote as $p_{1}$ and $p_{2}$ prices of two derivatives (say, options or futures) dependent on this variable $S$ and time $t$. As $S$ is itself dependent on time, these derivatives follow a generalized Wiener process, known as Ito process, where both variables are dependent on the value of the underlying variable and time. This is expressed as:

$$
d x=a(x, t) d t+b(x, t) d z
$$

Applying this concept to the derivatives $p_{1}$ and $p_{2}$ we obtain:

$$
d p_{1} / p_{1}=\mu_{1} d t+\sigma_{1} d z
$$

and

$$
d p_{2} / p_{2}=\mu_{2} d t+\sigma_{2} d z
$$

where $\mu_{1}, \mu_{2}, \sigma_{1}$, and $\sigma_{2}$ are functions of $S$ and $t$, as stated above, and $d z$ is the same Wiener process as that governing behaviour of the variable $S$. Taking the discrete versions of these expressions, the processes followed by $p_{1}$ and $p_{2}$ are given by:

and

$$
\Delta p_{1}=\mu_{1} p_{1} \Delta t+\sigma_{1} p_{1} \Delta z
$$

$$
\Delta p_{2}=\mu_{2} p_{2} \Delta t+\sigma_{2} p_{2} \Delta z
$$

The stochastic element $\Delta z$ can be eliminated from these two equations by creating an instantaneously riskless portfolio comprising of $\sigma_{2} p_{2}$ and $-\sigma_{1} p_{1}$ of the first and second derivative, respectively. In other words, the portfolio contains:

$$
\mathrm{P}=\left(\sigma_{2} p_{2}\right) p_{1}-\left(\sigma_{1} p_{1}\right) p_{2}
$$

and changes in value by:

$$
\Delta \mathrm{P}=\sigma_{2} p_{2} \Delta p_{1}-\sigma_{1} p_{1} \Delta p_{2}
$$

By replacing $\Delta p_{1}$ and $\Delta p_{2}$ by the corresponding expressions given in (6) and (7), we obtain:

$$
\Delta \mathrm{P}=\left(\mu_{1} \sigma_{2} p_{1} p_{2}-\mu_{2} \sigma_{1} p_{1} p_{2}\right) \Delta t
$$

Since the elimination of $\Delta z$ has rendered this portfolio instantaneously riskless, it by definition earns risk-free interest rate $r$, so the following holds:

$$
\Delta \mathrm{P}=r \mathrm{P} \Delta t
$$

Substituting the expressions for $\mathrm{P}$ and $\Delta \mathrm{P}$ given by (9) and (10), respectively, into (11) results in:

$$
\mu_{1} \sigma_{2}-\mu_{2} \sigma_{1}=\sigma_{2} r-\sigma_{1} r
$$

which can be rewritten as (Hull, 1997):

$$
\left(\mu_{1}-r\right) / \sigma_{1}=\left(\mu_{2}-r\right) / \sigma_{2}
$$

From the above, we can see that the difference between the expected return on a security and risk-free interest rate is related to the underlying volatility, whereby greater returns would be expected by investors for more volatile financial instruments in order for those to remain competitive in the market. This brings us to the market price of risk.

\section{Market Price of Risk}

If we denote the above ratio as $\lambda$, we can see that for any pair of $\mu$ and $\sigma$, the following holds:

$$
\lambda=(\mu-r) / \sigma
$$

As $\lambda$ and $\sigma$ are dependent on the original variable $S$ and time $t$, they are in general independent of the type and the characteristics of the derivative to which they apply (in this case $p_{1}$ and $p_{2}$ ). In other words, $\lambda$ represents the market price of risk associated with $S$.

Given that $\mu$ and $\sigma$ are the expected return on the derivative $p$ and its volatility, respectively, as the volatility increases, investors will demand greater difference between $\mu$ and $r$ (prevalent risk-free interest in the market), which is intuitive result. In this way, some of the very abstract concepts in financial calculus are related to the investments decisions made every day.

\section{Conclusion}

This paper does not present any innovative results. Its aim was to relate the key building blocks underlying models used to price even the most complex financial instruments with the 
apstraktnih koncepata finansijskog kalkulusa sa investicionim odlukama koje se donose svakoga dana.

\section{Zaključak}

Ovaj rad ne sadrži inovativne rezultate. Njegov cilj je bio da ključne gradivne segmente modela koji se koriste za utvrđivanje cena čak i najkompleksnijih finansijskih instrumenata dovede $\mathrm{u}$ vezu sa investicionom logikom većine investitora i da poveže apstraktivne koncepte finansijskog kalkulusa sa praksom donošenja investicionih odluka, što ne isključuje mogućnost šire elaboracije ovog pitanja.

\section{Literatura / References}

1. Cox, J., \& Rubnstein, M. (1985). Options Markets. Pretince Hall, New Jersey.

2. Ford, D. (1996). Mastering Exchange Traded Equity Derivatives. Pearson Education, Harlow, UK.

3. Grinstead, C. M., \& Snell, J. L. (1997). Introduction to Probability. American Mathematical Soc., Providence, Rhode Island.

4. Harrison, J. M. (1985). Brownian Motion and Stochastic Flow Systems. Wiley, New York.

5. Hull, J. (1997). Options, Futures and other Derivative Securities (3 ${ }^{\text {rd }}$ ed.). Pretince Hall, New Jersey.
6. Jarrow, R. J., \& \& Turnbull, S. (1996). Derivative Securities. South Western, Cincinnati.

7. Johnson, N. L., Kotz, S., \& Kemp, A. W. (1993). Univariate Discrete distributions (2nd ed.). Wiley, Hoboken, New Jersey.

8. Kushner, A. J. (1995). Numerical Methods for Stochastic Control Problems in Continuous Time. Springer-Verlag, Berlin.

9. Meyn, S., E Tweedie, R. L. (2009). Markov Chains and Stochastic Stability. Cambridge, Cambridge University Press. 
investment logic of most investors and to link the abstract concepts in financial calculus with the practical investment decision-making. This, however, does not preclude further exploration of this issue.

10. Morozov, A. N., E Skripkin, A. V. (2011). Spherical particle Brownian motion in viscous medium as non-Markovian random process. Physics Letters A., 375(46), 4113-4115.

11. Musiela, M., \& Rutkowski, M. (1997). Martingale Methods in Financial Modelling. Springer, New York.

12. Neftci, S. N. (2000). An Introduction to the Mathematics of Financial Derivatives ( $2^{\text {nd }}$ ed.). Academic Press, San Diego.

13. Shoesmith, E (1986). Huygens' solution to the gambler's ruin problem. Historia Mathematica, 13(2), 157-164.
14. Weiss, G. H. (1994). Aspects and Applications of the Random Walk. Random Materials and Processes. North-Holland Publishing Co., Amsterdam.

15. Wilmot, P., Howison, S., \& Dewyanne, J. (1995). The Mathematics of Financial Derivatives. Cambridge University Press, Cambridge.

16. Wilmott, P. (2007). Paul Wilmott Introduces Quantitative Finance (2 ${ }^{\text {nd }}$ ed.). John Wiley \& Sons, West Sussex. 